\title{
Elements of Smart Computer Graphics - A Potential Basis for New Experimental Method of Teaching and Learning
}

\author{
https://doi.org/10.3991/ijet.v15i13.13481 \\ Renáta Bernátová, Milan Bernát, Janka Poráčová \\ The University of Prešov, Prešov, Slovakia \\ Ladislav Rudolf \\ The University of Ostrava,Ostrava, Czech Republic \\ Andrea Kl’učarová $(\bowtie)$ \\ The University of Prešov, Prešov, Slovakia \\ andrea.klucarova@smail.unipo.sk
}

\begin{abstract}
This paper outlines the possibilities of implementing the elements of smart computer graphics (applets and animations) into the curriculum of science-oriented school subjects. Applet is a purposeful (especially educational) program, which was developed on the platform of modern elements of smart computer graphics. These elements allow us to visualize technical and natural objects, phenomena or processes in such a degree of clarity which cannot be achieved by traditional ways of visualisation or by using traditional technological techniques. To be more specific, thanks to computer animations and simulations it is possible to slow down, speed up or shred the processes over time as well as phenomena taking place in natural systems. Moreover, we are able to visualize objects that cannot be seen with the naked eye because of their size (too small or too large), inaccessibility to humans or, in-fact, their nonexistence. Application components called Interactive Computer Graphics (hypertext, drag and drop, etc.) as well as Flash animations included into the teaching-learning process are together with a comprehensive methodology of their application, a part of newly designed teaching method. The efficiency of this method is verified by pedagogical experiment.
\end{abstract}

Keywords-Modern elements of smart computer graphics, Experimental teaching and learning method

\section{Introduction}

There are several definitions characterising an applet. The following one is carefully chosen from Wikipedia. In our opinion, it gives relevant and sufficient information about the investigated object [1]. 
An applet is a software component that runs in the context of another programme, for example a web browser. An applet usually performs a very narrow function that has no independent use. Hence, it is an application. The term was introduced in AppleScript in 1993. An applet differs from the 'subroutine' in several features. Firstly, it operates only on the 'client' platform environment of a system, as contrasted from 'servlet'. As such, an applet provides functionality or performance beyond the default capabilities of its container (the browser). Also, in comparison to subroutine, certain capabilities are restricted by the container. The applet is written in a compiled language, while the scripting language of the container is an interpreted language, hence the greater performance or functionality of the applet. Unlike a 'subroutine', a complete web component can be implemented as an applet. This long definition; however, needs to be extended with a short description characterizing a Java applet from the methodological point of view. In our opinion, an applet is a 'small' special monofunctional application programme used for example for interactive animations or calculations made by a client himself without the need of cooperation with a server. When applied into the pedagogical process, a Java applet enables the teacher to create texts with simulations. Thus, it becomes an instrument for creating interactive teaching materials. (An annotation of this article contains our definition).

The main goal of this research is to create Flash animations and Java applets in order to improve the way of teaching natural (and technical) sciences. It is our intention to innovate the system of teaching university students of natural sciences in the teacher training programmes. For this reason, we have created over two hundred Java applets in the Java environment. The applets are made in the following way: static pictures and figures from traditional printed text books are being animated or simulated.

Finally, we intend to create a virtual visualisation 'supplement' that would extend the range of visualisation potential of traditional printed textbooks (as well as the potential of didactic construction kits). We attempt to maximise already existing tools and platforms and thus maximise the power and efficiency of visualisation.

Moreover, we demonstrate the way of applet creation and its didactic function on one of our applets. The creation principles, strategies and tactics are analogical for all applets. In general, the key point of using visualization may be explained as follows:

- The phenomena, processes and objects such as a) pictures or figures in a traditional textbook, b) model construction kits, c) other three-dimensional models are being visualised in a traditional (static) way

- The phenomena, processes and objects that go beyond the boundaries of traditional and conventional ways of visualisation are being visualized by means of Flash animations and Java applets ('enlargement of a hand of knowledge')

\subsection{Strategy and tactics of creating experimental way of visualization (applying elements of smart computer graphics in teaching-learning process)}

"The principled essence" of the difference between experimental and a traditional way of natural processes visualization is in our research associated with the dynamici- 
ty. While the traditional way of visualization is based on using "static" techniques of visualizing the natural and technical systems, in our experimental way of visualization also "dynamic" techniques are being used (computer modelling, computer simulations and their results presented by computer graphics - Fig. 1).

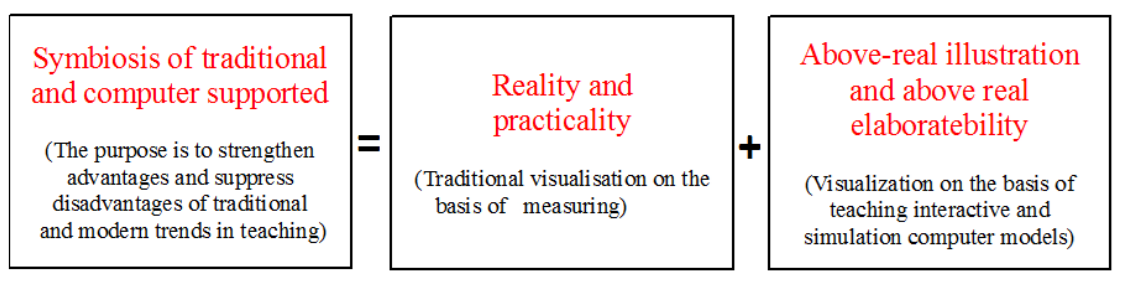

Fig. 1. Scheme of strategy and tactics of creating experimental way of visualization

The innovative experimental system (called NIESVA) was designed to eliminate the above-mentioned disadvantages of the existing (traditional) ways of visualization of natural processes for didactic purposes. The experimental way of visualization applied in the NIESVA enables us, except other functions, to accelerate, decelerate or run the action. It is not possible to do such actions during a real-time experiment and this impossibility is being understood as a disadvantage of a physical measuring. Furthermore, NIESVA enables us to interactively enter into the running visualization process and change the model parameters, which could not have been done in traditional video-animations. Finally, this experimental way of visualization is practical and pragmatic. On the other hand, the traditional visualization through computer simulation lacks these features. These NIESVA attributes (including multimedia and the synergic effect of mutual interconnection) also extends both, quality and quantity dimensions of a degree of didactic visualization demonstrability beyond the possibilities of all the above-mentioned traditional forms of visualization. In this research, we have also dealt with the issue of efficiency of using NIESVA method in science teaching in comparison to the traditional teaching methods (see the section - The Experimental Research).

\section{Applet Set Designed for Thematic Teaching in Natural Subjects Begins with "Do you Know Why / How?"}

On the contrary, the visualization by means of computer modelling may be improved by a practical and real attribute that is contained in a textbook or in a model construction kit but not in a computer model.

The created collection of computer models was called: "The world of natural and technical sciences (of younger pupils) in computer models (educational models designed for teaching natural sciences, technical work and essentials of ecological education at schools)". In order to strengthen the didactic function of computer models, each computer model was given an eloquent name. Each individual applet from cer- 
tain thematic unit starts with one of the following questions: How does it work/function? or Do you know why/Do you know how...?
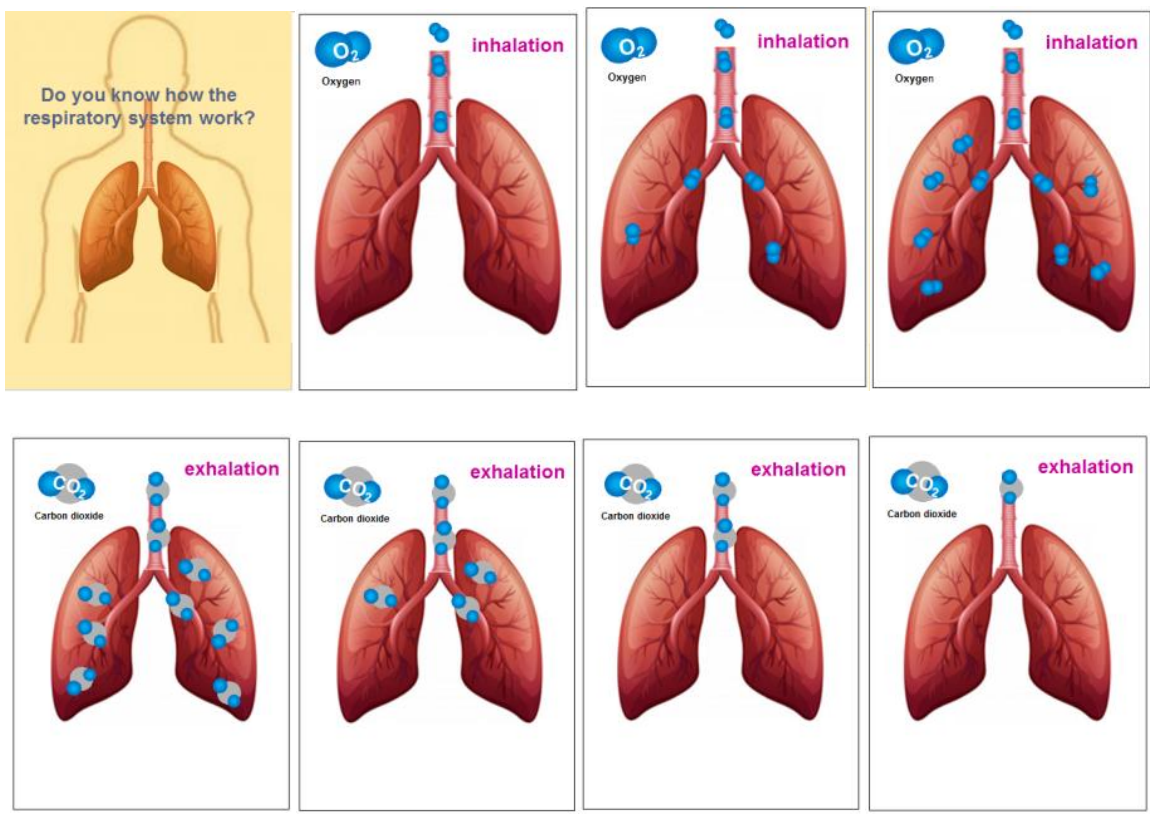

Fig. 2. The applet (key sequence) - Do you know how the respiratory system works? (source - author's own design).
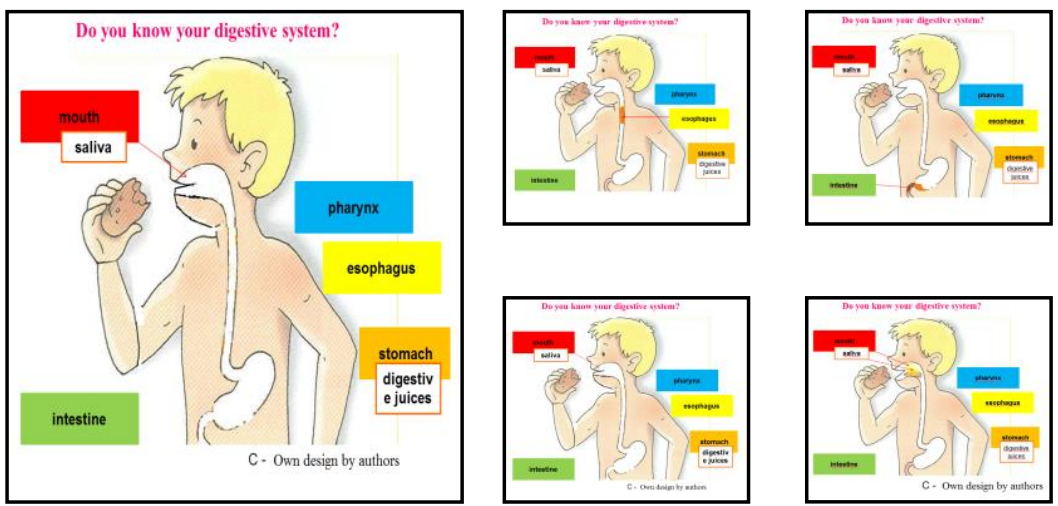

Fig. 3. The applet (key sequence) - Do you know your digestive system? (source - author's own design) [3].

Natural Science - Biology: Topic of human body (key sequence Fig. 2 - Fig. 6): How does the human body work? Do you know your digestive system? Do you know 
how it works? Do you know how your heart works? Do you know how the respiratory and circulatory systems work? Do you know how the musculoskeletal system works? Do you know how the nervous system works? Do you know how the endocrine system works? What do you know about human reproduction? How does the reflex arch work? How does the sense of sight work? How does the sense of smell work? How does the sense of touch work?

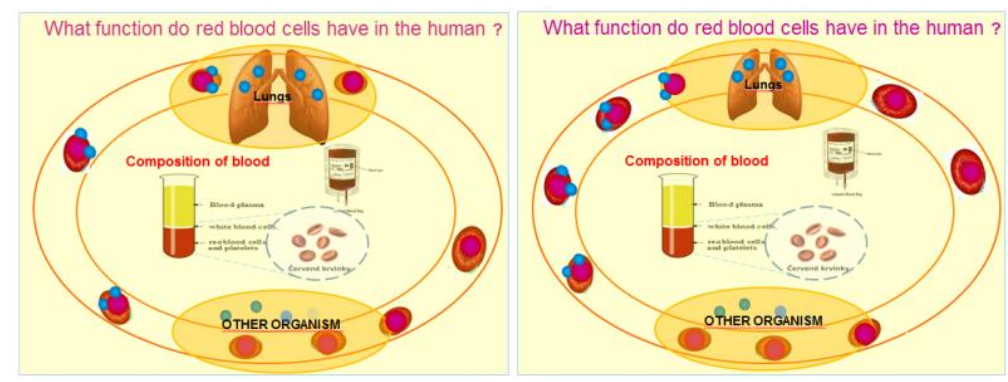

Fig. 4. The applet (key sequence)- What function do the red blood cells have in human body? (source - author's own design)

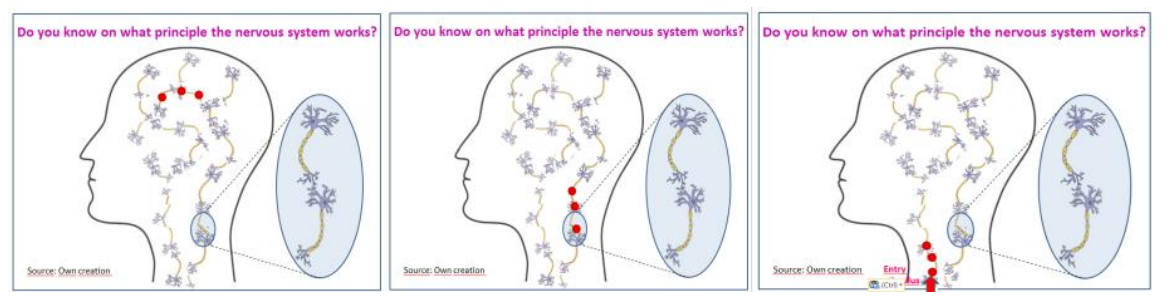

Fig. 5. The applet (key sequence)- Do you know the principle which the nervous system works on?

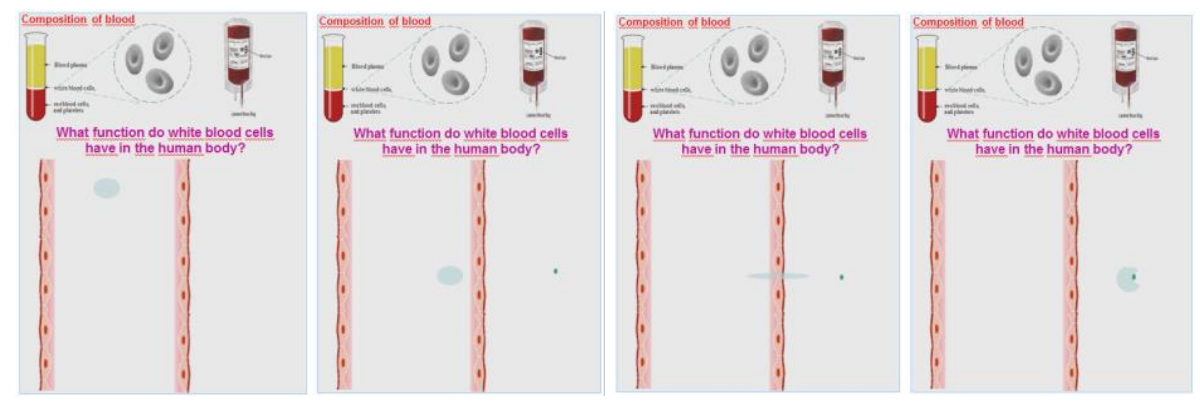

Fig. 6. The applet (key sequence) - What function do the white blood cells have in human body? (source - author's own design).

Natural Science - Ecology, Physics (key sequence Fig. 7 - Fig.8): How do we affect the environment? How does the hydrological cycle work? - How does the nitro- 
gen cycle in the nature work? The applet of photosynthesis (nutrition and growth) of plants.
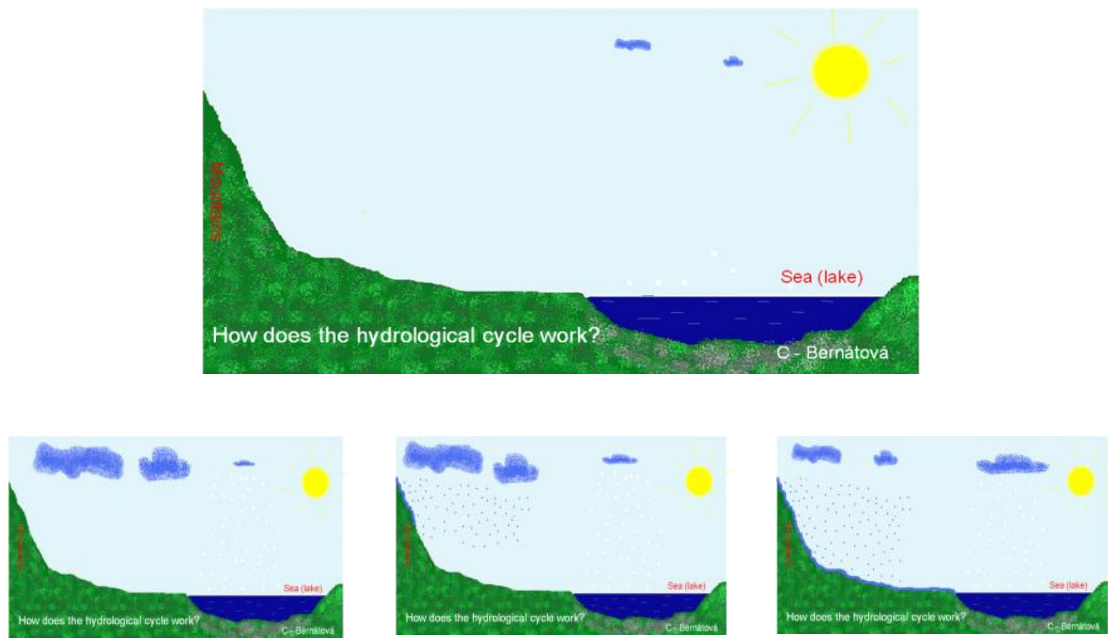

Fig. 7. The applet (key sequence) - How does the hydrological cycle work? [2]
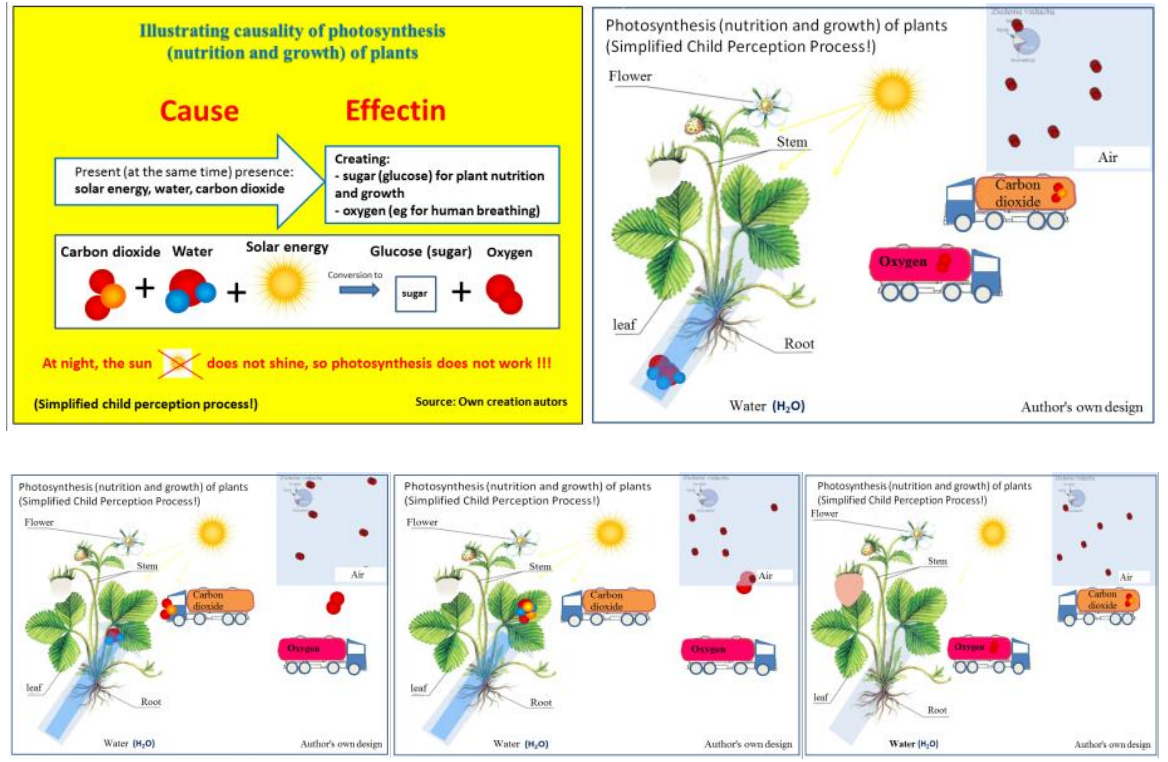

Fig. 8. The applet (key sequence) - Photosynthesis (nutrition and growth) of plants. 

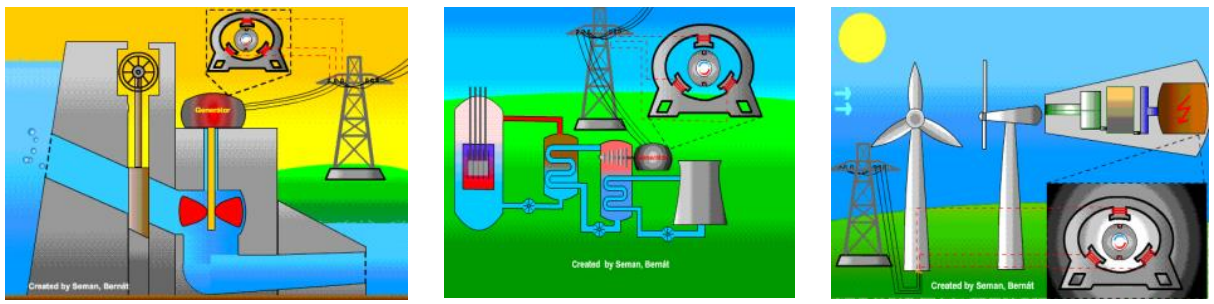

Fig. 9. The Flash animation (key sequence) - How is electrical energy made in hydroelectrical power station? How is electrical energy made in photovoltaic power station? How is electrical energy made in nuclear power station? How is electrical energy made in wind power station?
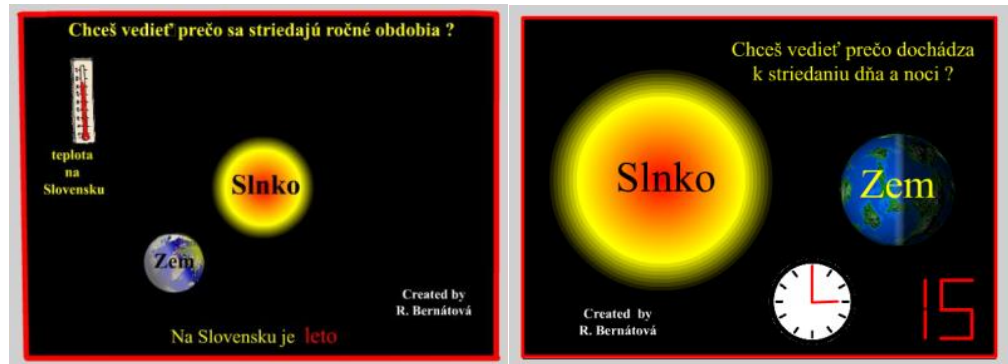

Fig. 10.The applet (key sequence) - Do you want to know why seasons alternate? Do you want to know what causes a day-night cycle?

\section{Experimental Research of Java Applets Utilization in Teaching-learning process}

We have made a database of Java applets as a platform for the creation of experimental innovative teaching method called NIESVA. It has been carefully designed to visualise the natural processes and phenomena through applets. During our research the NIESVA method (in the form of specific models designed for teaching certain topics (at pedagogical faculties) was also experimentally verified.

\subsection{Experimental verification of applets' didactic efficiency in the conditions of real schools}

A pedagogical experiment was used to compare the two different teaching methods applied on experimental group (the NIESVA method) and a control group (traditional teaching method). The principle of this pedagogical experiment is demonstrated in Fig. 13. The experimental teaching method is being demonstrated, too. 


\begin{tabular}{|c|c|}
\hline \multicolumn{2}{|c|}{ Common Features } \\
\hline $\begin{array}{c}\text { In both the experimental and control groups an identical } \\
\text { technical object, phenomenon, or process were visualised }\end{array}$ \\
\hline \multicolumn{2}{|c|}{ Different Features } \\
\hline The control group & The experimental group \\
\hline $\begin{array}{c}\text { - a traditional technique of } \\
\text { visualisation using static } \\
\text { pictures in a textbook, } \\
\text { transparencies } \\
\text { (an overhead projector) }\end{array}$ & $\begin{array}{c}\text { - an experimental technique } \\
\text { of visualisation by means of } \\
\text { a Java applet using } \\
\text { computer animation and } \\
\text { simulation }\end{array}$ \\
& $\begin{array}{r}\text { (an LCD projector) } \\
\hline\end{array}$
\end{tabular}

Fig. 11.The principle of the pedagogical experiment [1]

The main aim of the experimental research was to investigate the possibilities of the NIESVA method application into the school environment in order to increase the efficiency of the teaching-learning process.

\subsection{Initial hypothesis of the research}

H: The initial hypothesis claims that the proposed experimental teaching method (called NIESVA) will be more efficient than the traditional one. In order to succeed in verifying this hypothesis quantitatively and qualitatively, we divided the initial hypothesis into the following sub-hypotheses:

H1: The cognitive learning performances (the results of the didactic output test) of the students taught by means of the NIESVA method will be better than of those taught by applying traditional methods.

H2: At the end of the experimental period, students taught by NIESVA method will achieve better or the same level of memory performance in comparison to students who were taught in a traditional way. It is related to remembering and memorizing new information they have been taught (in the subtest $\mathrm{N} 1$ of the didactic output test - according to the Niemierko's taxonomy of educational objectives.

H3: At the end of the experimental period, students taught by NIESVA method will achieve better or the same level of knowledge comprehension (in the subtest N2 of the didactic output test - according to the Niemierko's taxonomy of educational objectives) compared to the students who were taught in a traditional way.

We present here only the central sub-hypotheses concerning the cognitive area. The efficiency of using the NIESVA method in teaching Natural Sciences at universities was tested during a continuous series of a long-term empirical research throughout the years 2015 and 2016. The research sample consisted of 64 university students of Natural Sciences attending teacher-training study programmes. According to the results achieved in the didactic input test, they were divided into the experimental and a control group. Thirty-three students were placed into the experimental group and 31 
students into the control group. Pedagogical experiment was carried out from January 2015 to June 2016. In this research, the following pedagogical and psychological research methods were used: 1/ a pedagogical experiment - the main method, a twogroup model of the experiment (consisting of an experimental and a control group) conducted synchronously and simultaneously; 2/ didactic tests, 3/ questionnaire, 4/ interviews, 5/ method of observation, 6/ statistical methods of research data analysis.

\subsection{Main results of pedagogical research}

Verbal interpretation of the research data analyses is quite concise as a matter of fact that included graphs are clear enough - Fig. 14 and Fig. 15. They contain digital data related to the values in questions as well as the basic characteristics of the statistical data arranged into the tables. We consider the graphs eloquent; therefore, we do not provide any additional verbal explanation for them. - TABLE 1.

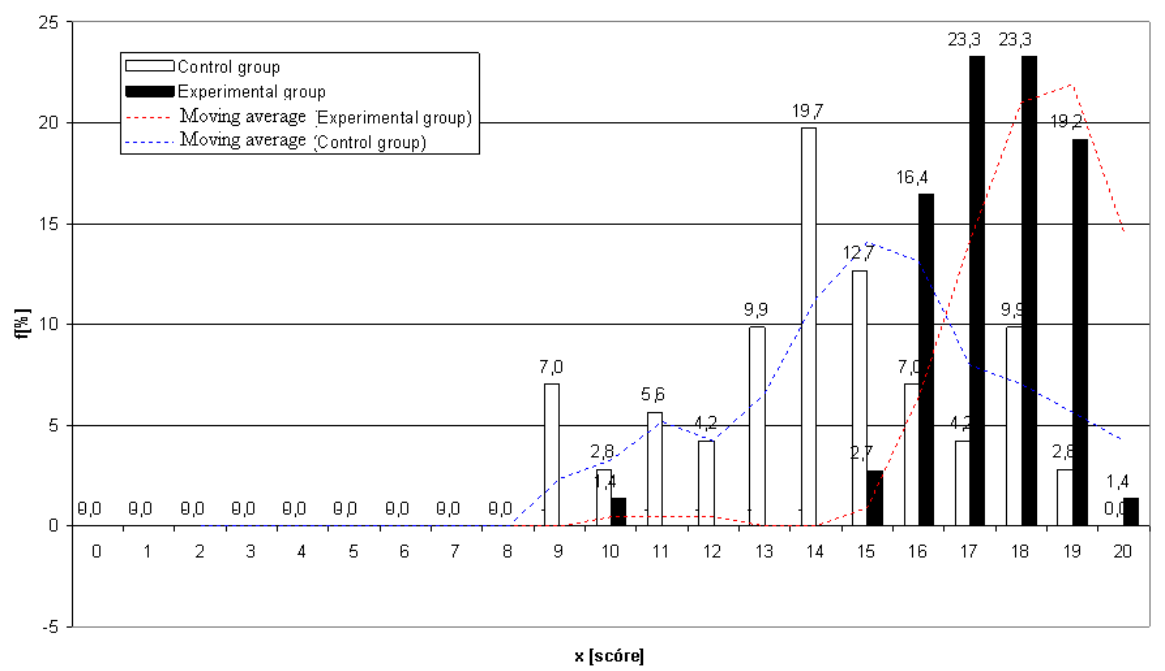

Fig. 12.Frequency distribution of learners' performances achieved in the final didactic test within the pedagogical experiment 
Table 1. Descriptive and Inductive Statistics

\begin{tabular}{|c|c|c|c|c|c|c|}
\hline \multicolumn{7}{|c|}{ Descriptive Statistics } \\
\hline TAB 1.1E & $X \max E=$ & 20 & $\mathrm{X} \min \mathrm{E}=$ & 11 & BverageE = & 17,35484 \\
\hline EXP & test.norn & yes & MedianE= & 17 & Mode $\mathrm{E}=$ & 17 \\
\hline 0. quartile = & 11 & 1.quartile & 16 & 2. quartile= & 17 & \\
\hline 3.quartile = & 18 & 4.quartile & 20 & & & \\
\hline \multicolumn{7}{|c|}{ Descriptive Statistics } \\
\hline TAB 1.1C & $\mathrm{X} \max \mathrm{C}=$ & 19 & $\mathrm{X}_{\min \mathrm{C}}=$ & 9 & AverageC & 14,42188 \\
\hline $\mathrm{CON}$ & test.norm. & yes & Median $\mathrm{C}=$ & 14 & Mode $\mathrm{C}=$ & 14 \\
\hline 0.quartile= & 9 & 1.quartile = & 13 & 2. quartile= & 14 & \\
\hline 3. quartile= & 16 & 4. quartile= & 19 & & & \\
\hline
\end{tabular}

Inductive Statistics

\begin{tabular}{|c|c|c|c|c|c|c|}
\hline \multicolumn{2}{|c|}{ Stat. confid. (E-C) } & $\mathrm{k}=2$ & ni1 $=$ & 1 & ni $2=$ & 62 \\
\hline $\mathrm{Fkr}[95 \%]=$ & 6,8 & $\mathrm{Fwyp}=$ & 94,14889 & signifik $=$ & áno & \\
\hline $\mathrm{Fkr}[99 \%]=$ & 3,9 & & & & & \\
\hline
\end{tabular}

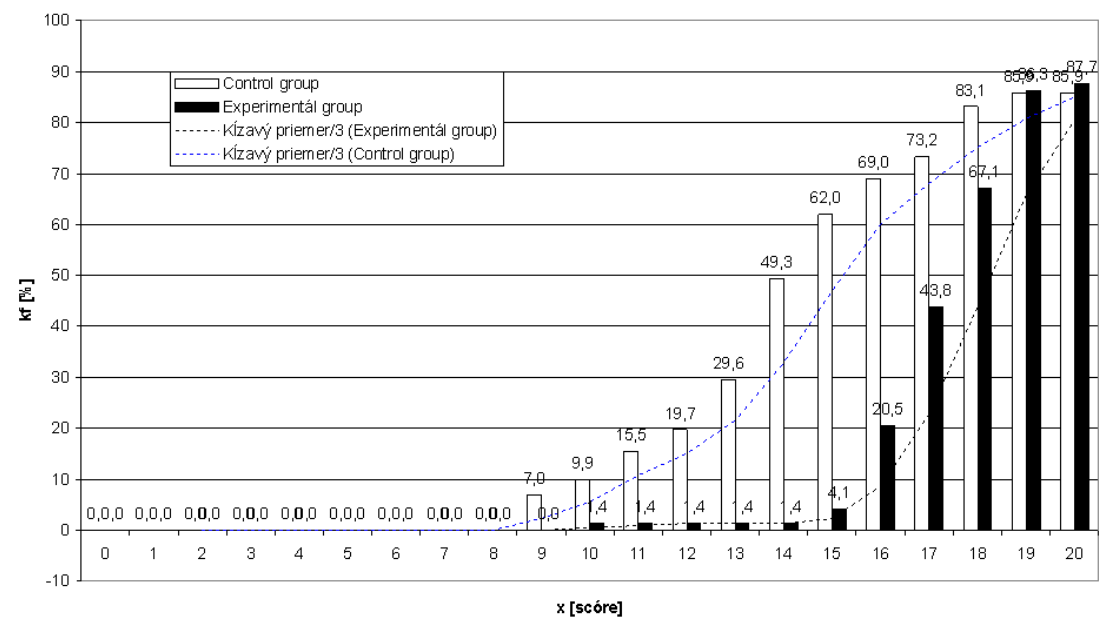

Fig. 13. Distributive function of learners' scores achieved in the final didactic test within the pedagogical experiment 
3.4 Some results of the structural statistical analysis on the level of subtests system created on the basis of Niemierko's taxonomy of educational objectives

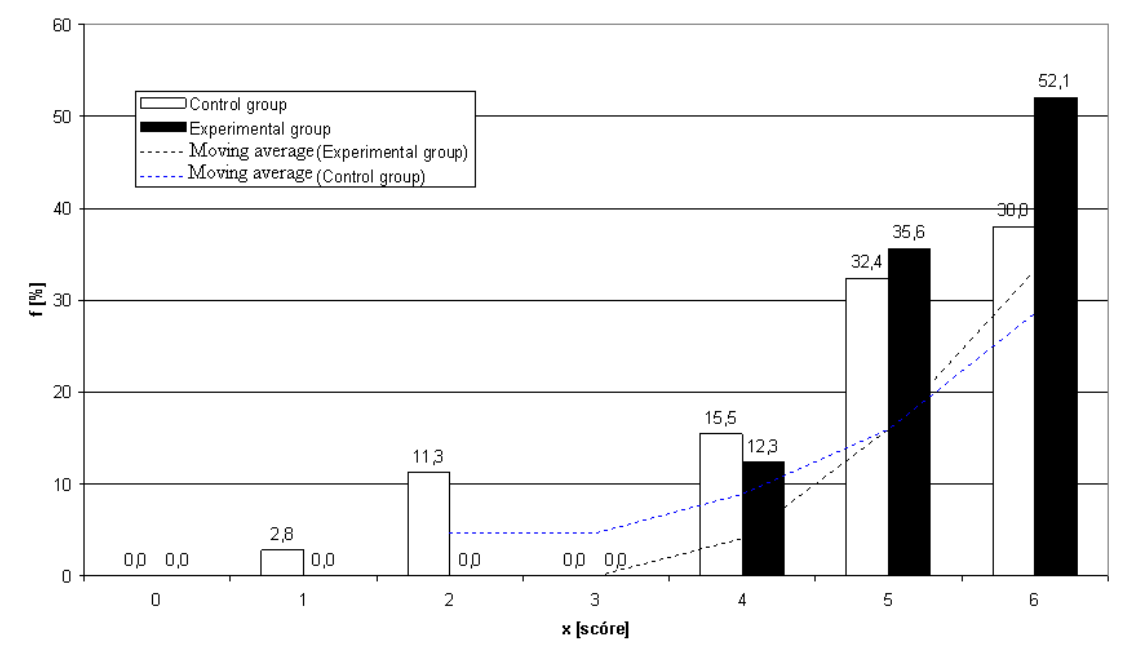

Fig. 14.Frequency distribution of learners' performances achieved in subtest N1 (remembering) of the final didactic test within the pedagogical experiment

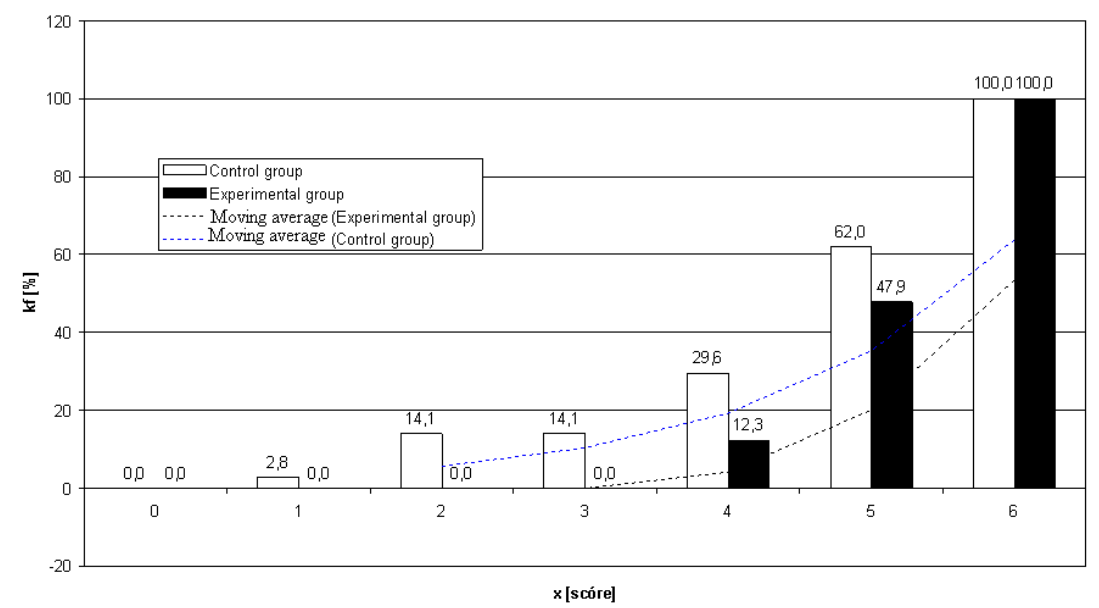

Fig. 15.Distributive function of learners' performances achieved in subtest N1 (remembering) of the final didactic test within the pedagogical experiment 


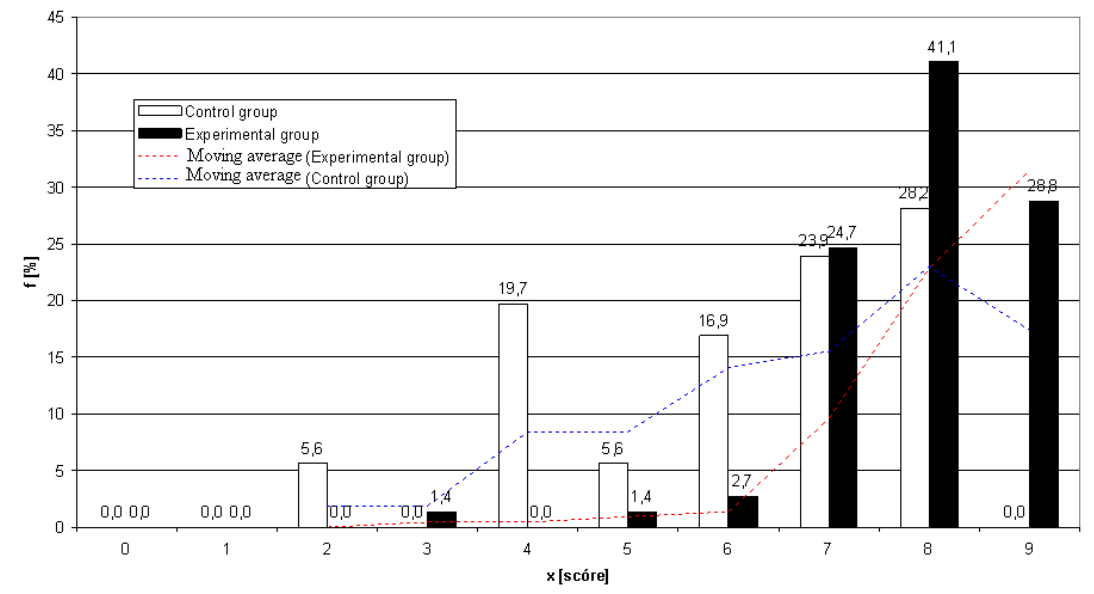

Fig. 16.Frequency distribution of learners' performances achieved in subtest N2 (comprehension) of the final didactic test within the pedagogical experiment

There are frequency distribution graphs (Fig. 16, Fig. 18 and Fig. 20) of subtests N1, N2 and N3 together with their distribution functions (Fig. 17, Fig. 19 and Fig. 21)

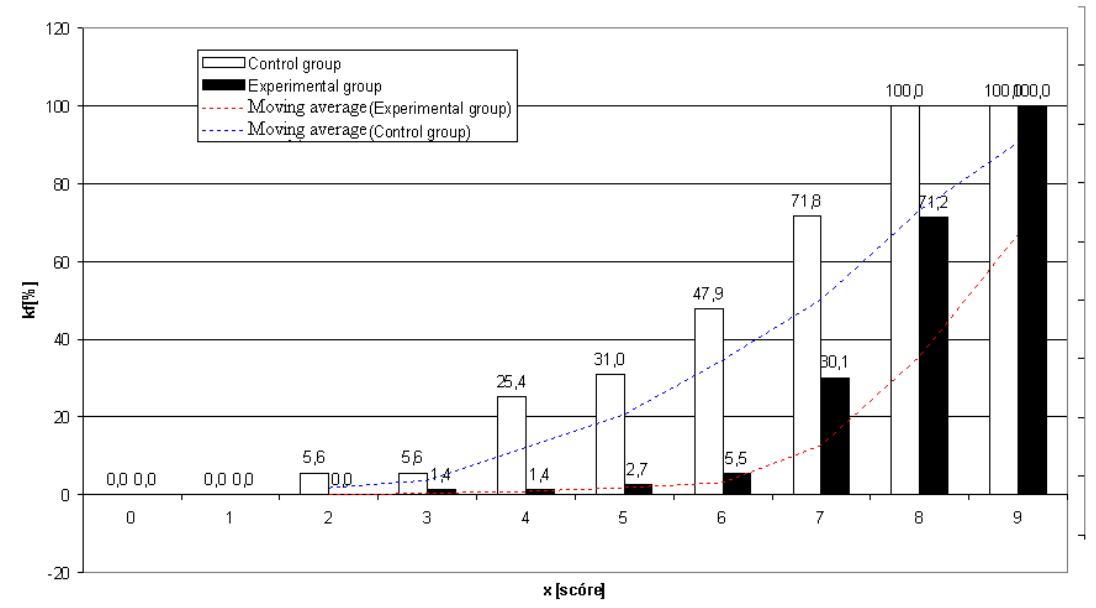

Fig. 17. Distributive function of learners' scores achieved in subtest N2 (comprehension) of the final didactic test within the pedagogical experiment 
Paper-Elements of Smart Computer Graphics - A Potential Basis for New Experimental Method...

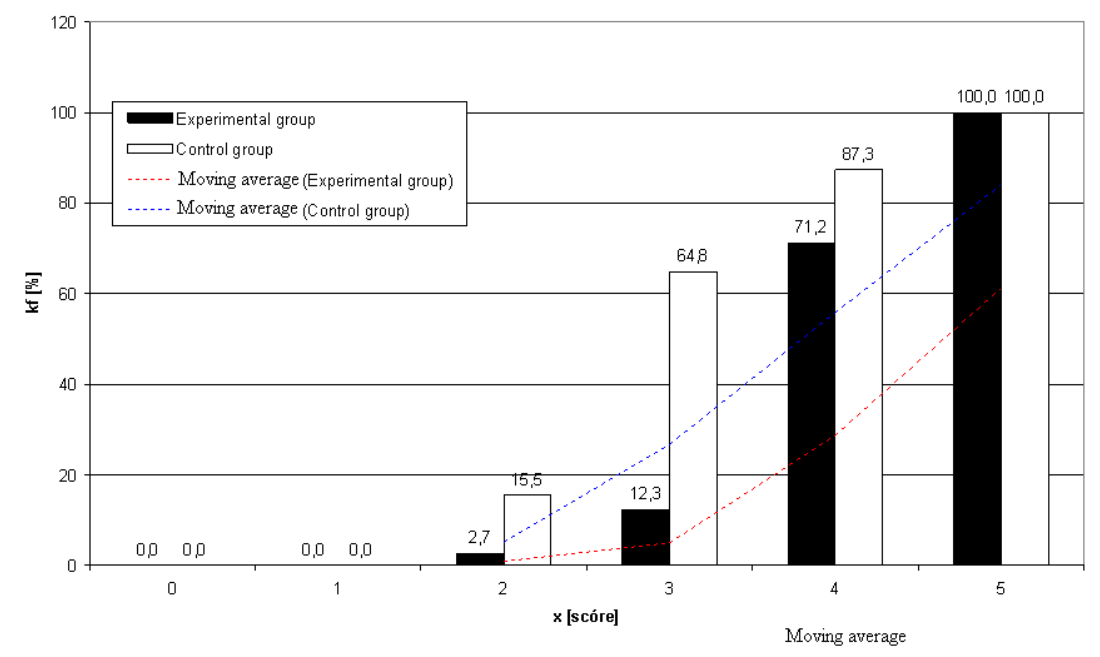

Fig. 18. Frequency distribution of learners' performances achieved in subtest N3 (application) of the final didactic test within the pedagogical experiment

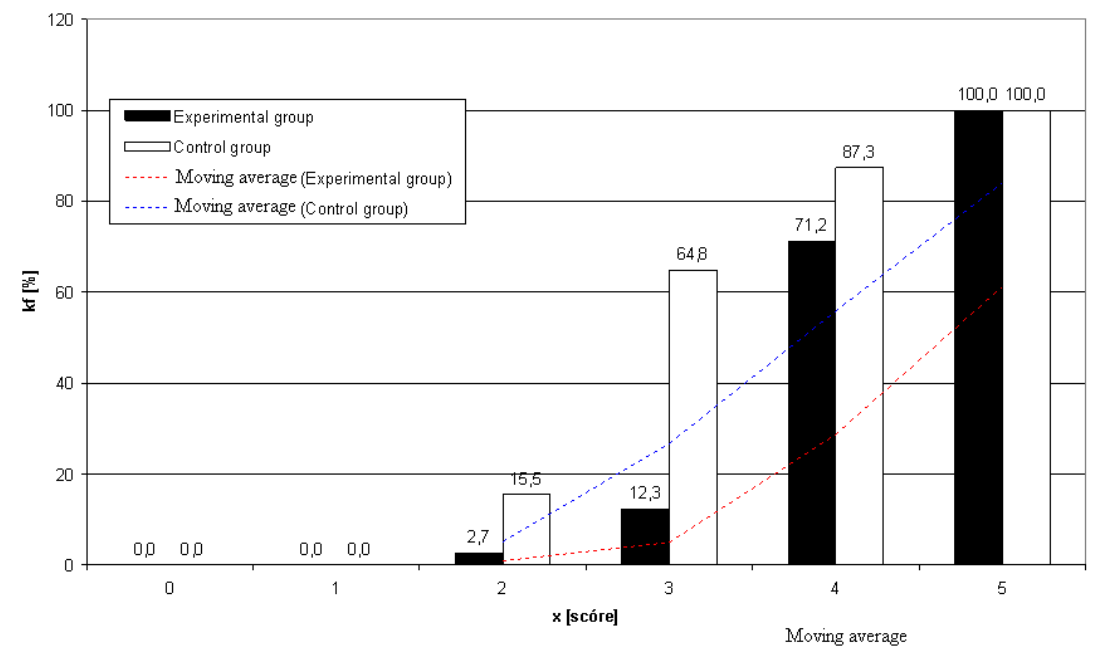

Fig. 19. Distributive function of learners' scores achieved in subtest N3 (comprehension) of the final didactic test within the pedagogical experiment 


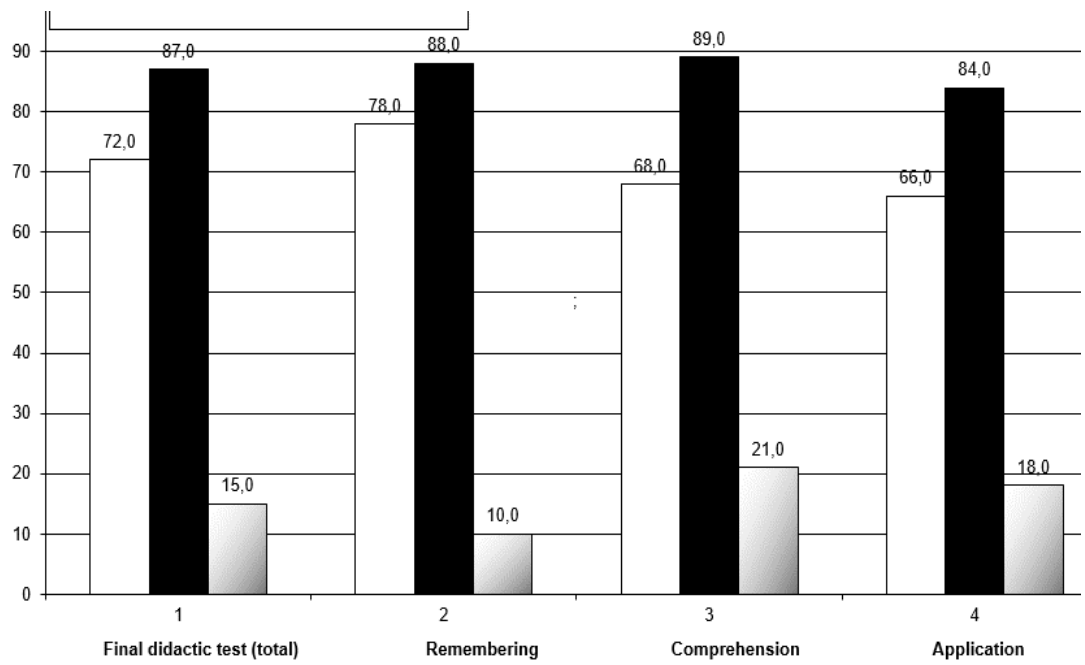

Fig. 20.Comparison of the success rate of each subtest from the final didactic test oriented on assessing the educational objectives (remembering, comprehension, application) in the experimental and control group

Results of the quartile and cluster statistical analysis are shown in Fig. 23

\subsection{Some results of the quartile and cluster statistical analysis}
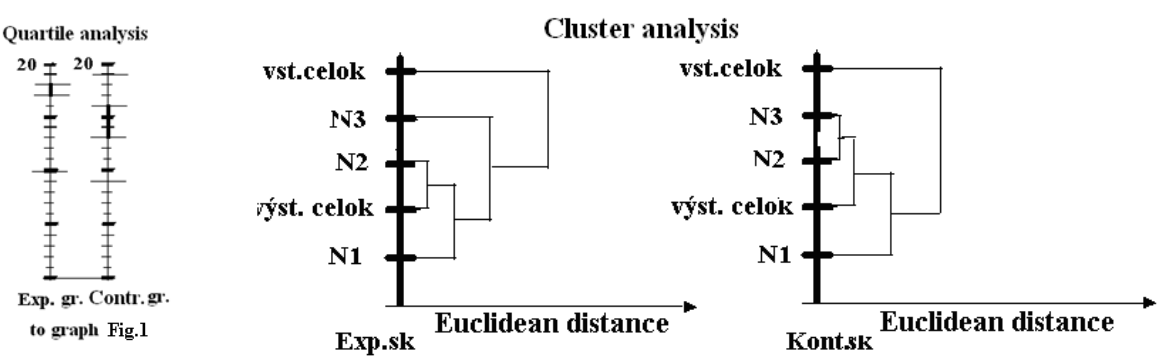

Fig. 21.Results of the quartile and cluster statistical analysis

\section{Conclusions and Recommendations Resulting from the Research Data Analysis}

Our arguments are strengthened by the results presented in Fig. 22. They demonstrate the comparison of the success rate of each subtest from the final didactic test oriented on assessing the educational objectives (remembering, comprehension, application) in the experimental and control group. The results show that between the experimental and control group there are some differences in the success rate of each 
subtest as follows: $10.0 \%$ in level of remembering, $21.0 \%$ in level of comprehension, $18.0 \%$, in level of application and $15.0 \%$ in final score reached in didactic output test always in favour of the experimental group (see Fig. 22, Fig.23). Our statements are also supported by the results shown in the Table 1 (Descriptive and inductive statistics). The statistical significance of performance differences between the students of experimental and control group is calculated from the final didactic test and demonstrated as a whole in the TABLE 1 called Descriptive and inductive statistics (by the analysis of variance $-F$ test). The value of calculated $F$ is $94.14, F k r=6.8$. Since $F>$ Fkr, we can say that there is a statistically significant difference in the final scores of experimental- and control- group students with the significance level of 0.05 . The interpretation of each subtest results, meaning subtest N1 (remembering), N2 (comprehension), N3 (application), is analogical to the previous one. (See Table 1 Descriptive and Inductive statistics).

Finally, we dare to say that the proposed experimental teaching method called NIESVA, which was used during this research, appears to be more effective than the traditional teaching method. Students who participated in this pedagogical experiment show better performance results in cognitive learning as well as in all other observed parameters (remembering, comprehension, application).

One of the things we consider the most encouraging in this work is the fact that NIESVA innovative teaching method may have been implemented into the teachinglearning process (during our research) without any radical changes in the traditional way of teaching. In our opinion, this is the biggest advantage of the NIESVA method. NIESVA method is an innovative teaching method based on active use of computer animations and simulations. They demonstrate the natural and technical processes and phenomena by means of Java applets. The overall analysis of the results proves good perspective for implementing it into the teaching practice. Moreover, it proves the system to become a useful tool for increasing the efficiency of teaching university students at pedagogical faculties. Furthermore, the research provides us with the clear evidence of achieving positive qualitative changes in students' knowledge structure. In addition, the participants of this research consider the NIESVA method more attractive and more motivating than the traditional methods. Except this, the members of the experimental group stated that every lesson, they were looking forward to working with Java applets.

Research results confirm that the implementation of Java applets into teaching natural sciences and technical subjects is of great didactic importance. It broadens the horizon of visualization, application, didactic and educational possibilities which cannot be reached by traditional techniques of visualization of objects, processes and phenomena. This is also true as it comes to teaching electrical engineering.

\section{Acknowledgement}

This research paper is published as the output of the project VEGA 1/0147/19 Research on the degree of correlation between knowledge and skills to solve technical problems in Vocational and Technical Education, Faculty of Natural Sciences UMB. 


\section{$6 \quad$ References}

[1] Bernát, M. (2005): Visualization of some electro-physical process through computer for didactic purposes and its application in teaching electrotechnical subjects. $\mathrm{PhD}$. Thesis, PdF UKF Nitra 2005

[2] Bernátová R.(2001): Proposal for use of visualization of logical foundation of subject matter and its ways of application in connection with elevating effectiveness of a teaching process., Rokus 2001, Prešov, ISBN 80-89055-08-7.

[3] Bernátová, R., Bernát, M., Cimbala, R (2009).: On Increasing Efficiency in Teaching Technical and Natural Sciences by Means of JAVA Applets II. (Experimental Research), Journal of Technology and Information Education, vol. 1 issue 1, 2009. https://doi.org/10.5507/jtie.2009.010

[4] Huiping Guo, Lin Zhu, Fengxin Yan (2016): Research on Key Techniques for Enginery Teaching Platform Based on Computer Dynamic Simulation Technique in, International Journal of Emerging Technologies in Learning (iJET) - eISSN: 1863-0383, Vol 11, No 08 (2016) page 54-58. https://doi.org/10.3991/ijet.v11i08.6049

[5] Chang Pan (2016): Design and Application of Multi-screen VR Technology in the Course of Art Painting International Journal of Emerging Technologies in Lear-ning (iJET) eISSN: 1863-0383, Vol 11, No 09 (2016) page 56-60. https://doi.org/10.3991 /ijet.v11i09.6126

[6] Melezinek A. (1986) Ingenieurpädagogik: Praxis der Vermitᄀtlung technische Wissens techn. Wissens. Wien, New York, Springer, 1986.

[7] Yanqun He (2015):: Application of Panoramic Image Technology in Distance Teaching System, International Journal of Emerging Technologies in Learning (iJET) - eISSN: 1863-0383, Vol 10, No 6 (2015) page 27-31. https://doi.org/10.3991/ijet.v10i6.4848

[8] Bernátová, R., Bernát, M., Cimbala, R. (2009).: On Increasing Efficiency in Teaching Technical and Natural Sciences by Means of JAVA Applets I. (Experimental Research), Journal of Technology and Information Education, vol. 1 issue 1, 2010. https://doi.org/10.5507/jtie.2009.010

[9] Melezinek A. (1986): Ingenieurpädagogik: Praxis der Vermittlung technische Wissens techn. Wissens. Wien, New York, Springer, 1986.

[10] Turek, I. (2016): Didaktika. Bratislava: Wolters Kluwer. ISBN: 978-80-8168-004-5.

\section{$7 \quad$ Authors}

Renáta Bernátová was born in Prešov, Slovakia, in 1966. She graduated from the Faculty of Natural Sciences of Pavol Jozef Šafárik University in Košice. She was awarded the RNDr. degree from the Faculty of Natural Sciences of Pavol Jozef Šafárik University in Košice, then Doc. and PhD. degrees from the Faculty of Education of Constantine the Philosopher University in Nitra. renata.bernatova@unipo.sk

Milan Bernát was born in Košice, Slovakia, in 1959. He was awarded the Ing. (MSc) engineer's degree in Electrical Engineering from the Faculty of Electrical Engineering and Informatics, Technical University of Košice, in 1983. He gained the $\mathrm{PhD}$. doctorate from the Faculty of Electrical Engineering and Informatics, Technical University of Košice, in 2001 (thesis [1])

Janka Poráčová is a dean of the Faculty of Humanities and Natural Sciences of Prešov University in Prešov, Slovak republic. She received a MVDr. degree (D.V.M. 
- Doctor of Veterinary Medicine - in 1985), Doc. degree (2001), Prof. degree (2015), both from the Faculty of Natural Sciences, Constantine the Philosopher University in Nitra.

Ladislav Rudolf was born in Olomouc (Czech Republic), on May 2, 1960. He graduated from the VŠB - Technical University of Ostrava, Faculty of Electrical Engineering and Computer Science in Ostrava (Czech Republic), in 1994. He received his $\mathrm{PhD}$. degree in Electrical Engineering from the VS̆B - Technical University of Ostrava (Czech Republic), in 2003.

Andrea Kl'učarová graduated from The University of Prešov in 2019. She received her master's degree (Mgr.) in Teaching Physics and English language and literature. She received her engineer's degree (Ing.) in Physical Engineering of Progressive Materials. Currently, she is a post-graduate student at the Department of Physics, Mathematics and Technology at The University of Prešov.

Article submitted 2020-01-31. Resubmitted 2020-03-24. Final acceptance 2020-03-24. Final version published as submitted by the authors. 